\title{
Patterns of the parasite communities in a fish assemblage of a river in the Brazilian Amazon region
}

\author{
Raimundo Rosemiro Jesus Baia ${ }^{1,2}$, Alexandro Cezar Florentino², \\ Luís Maurício Abdon Silva ${ }^{3}$ and Marcos Tavares-Dias ${ }^{1 *}$
}

\author{
${ }^{1}$ Embrapa Amapá, Macapá, Amapá, Brazil; ${ }^{2}$ Postgraduate Program on Tropical Biodiversity, Federal University of Amapá, Macapá, \\ Amapá, Brazil; ${ }^{3}$ Institute of Scientific and Technological Research of the State of Amapá (IEPA), Macapá, Amapá, Brazil
}

\begin{abstract}
This paper characterizes the pattern of ectoparasite and endoparasite communities in an assemblage of 35 sympatric fish from different trophic levels in a tributary from the Amazon River system, northern Brazil. In detritivorous, carnivorous, omnivorous and piscivorous hosts, the species richness consisted of 82 ectoparasites and endoparasites, but protozoan ectoparasites such as Ichthyophthirius multifiliis, Piscinoodinium pillulare and Tripartiella sp. were dominant species predominated, such that they were present in $80 \%$ of the hosts. The taxon richness was in the following order: Monogenea $>$ Nematoda $>$ Digenea $>$ Crustacea $>$ Protozoa $>$ Acanthocephala $=$ Cestoda $>$ Hirudinea. Among the hosts, the highest number of parasitic associations occurred in Satanoperca jurupari, Aequidens tetramerus, Hoplerythrinus unitaeniatus, Hoplosternum littorale, Cichlasoma amazonarum, Chaetobranchus flavescens, Squaliforma emarginata, Chaetobranchopsis orbicularis and Hoplias malabaricus. A weak positive correlation between ectoparasite abundance and length of the hosts was observed. Ectoparasite communities of detritivorous, carnivorous and omnivorous hosts were similar, but these differed from the communities of piscivorous hosts. Larval endoparasite species with low host specificity were the main determinants of the parasite infracommunity structure of the fish assemblage. Fish assemblage had few species of helminth that were specialist endoparasites, while many were parasites at the larval stage, infecting intermediate and paratenic hosts. Finally, carnivorous and omnivorous hosts harbored endoparasite communities that were more heterogeneous than those of detritivorous and piscivorous hosts. This result lends supports to the notion that the feeding habits of the host species are a significant factor in determining the endoparasites fauna.
\end{abstract}

\section{Keywords}

Amazon, Brazil, trophic level, parasites

\section{Introduction}

Part of the Amazon river system consists of várzea, i.e. floodplains alongside the rivers. These are areas that are seasonally inundated by the rivers and form very rich ecosystems that support complex trophic webs. The Amazon river basin has diverse tributaries draining its water levels, which vary enormously during the year. Most tributaries of the Amazon river system are accompanied by large fringing floodplains of differing shape and vegetation cover, which vary according to the flood regime and regional climate. These factors strongly influence the communities of invertebrates and fish that inhabit these areas (Garcez et al. 2017). These environments are important habitats for various native fish species, given that they provide feeding, reproduction and nursery areas.
Understanding parasites community structures in wild fish populations has been the topic of numerous studies, in which the roles of interactive and/or non-interactive processes have been addressed. Parasites provide an interesting model for studies on organization and structure of parasite communities in wild fish populations (Marcogliese 2002; Bittencourt et al. 2014a; Alcântara and Tavares-Dias 2015; Tavares-Dias et al. 2014; Hoshino et al. 2016; Ruehle et al. 2017). One important point that has been highlighted is the role of interactions, mostly in relation to the trophic level of the fish population, in determining the parasite abundance and species richness (Luque and Poulin 2008; Valtonen et al. 2010; Poulin and Leung 2011; Timi et al. 2011; Beevi and Radhakrishnan 2012). Wild fish populations can generally harbor ectoparasite and endoparasite species of diverse taxa, which display a variety of strategies in their life cycles, which may be either direct or indirect. 
Many parasite species, particularly endoparasites, have life cycles that involve transmission through a trophic web of intermediate, paratenic and definitive hosts. Among these, endohelminths are uniquely suited for providing information about trophic interactions because they possess complex life cycles that, for completion, require multiple hosts at different trophic levels. Transmission is often dependent on predatorprey relationships (Luque and Poulin 2008; Valtonen et al. 2010; Beevi and Radhakrishnan 2012). Thus, the trophic levels of hosts have been used as predictors in studies on the trophic web of fish assemblages. The assumption in doing this has been that host species at higher levels would be exposed to greater numbers of infective endohelminth larvae from a broader range of parasite taxa through their diet than would those at lower trophic levels over evolutionary time (Choudhury and Dick 2000; Luque and Poulin 2008; Valtonen et al. 2010). However, earlier studies also suggested that fish species in the middle of food webs, which feed on both invertebrates and small fish, should harbor the greatest richness of endoparasite species (Marcogliese 2002).

In contrast, the ectoparasite species infect their hosts through active dispersion, allowing them to be more specific in their host choices. In addition, transmission of ectoparasites is unaffected by the feeding habits and ontogenetic changes of their hosts, or the availability of different prey species in the environment (Valtonen et al. 2010; Salgado-Maldonado et al. 2016).

In fish populations, the body length of hosts has emerged as a significant predictor of the burden of parasites (Grutter 1994; Poulin 2004a; Poulin and Leung 2011). Several studies on fish populations have shown that parasite abundance increases or decreases according to host age (Grutter 1994; Poulin 2004a; Valtonen et al. 2010). However, any relationship between the body size of the fish and the burden of parasites using it as an intermediate host should be positive, because large hosts are unlikely to serve as prey. Interest in the patterns and process of parasite communities in freshwater fish assemblages of tropical areas have been demonstrated in several studies (Guégan et al. 1992; Choudhury and Dick 2000; Poulin 2001; Pérez-Ponce de León and Choudhury 2005; Luque and Poulin 2008; Bellay et al. 2013; Bellay et al. 2015; SalgadoMaldonado et al. 2016). Factors such as the biogeography, ecology of both tropical freshwater fish and parasites, as well as environmental conditions, all contribute towards parasites fauna in such studies. Nevertheless, we know little about parasite communities structure in fish assemblages from the South American tropics, though these approaches are important because they provide a representation of local diversity and define the possible patterns of these communities. Parasites community structure in fish assemblages in the Amazon region also have been little addressed. Hence, it is no surprise that the true diversity of parasites of Amazonian fish is poorly understood, given that they form an invisible fauna.

In this paper, we investigated the pattern of the communities of ectoparasites and endoparasites of an assemblage of sympatric fish at different trophic levels in a tributary of the Amazon river system, in Brazil. We tested two main hypotheses: (i) detritivorous, omnivorous, carnivorous and piscivorous hosts in a basin within the Amazon river system present dissimilar patterns of ectoparasites and endoparasites; and (ii) the length of hosts influences the abundance of ectoparasites and endoparasites.

\section{Materials and Methods}

\section{Fish and study area}

This study used the fauna of 82 species of ectoparasites and endoparasites distributed in 1574 fish of 35 host species in 12 families (Table I). We collected the fishes between 2011 and 2016 in the Igarapé Fortaleza basin (Fig. 1), which is a tributary of the Amazon river system in the state of Amapá, northern Brazil. All fishes were collected with nets of different mesh size.

The Igarapé Fortaleza hydrographic basin (Fig. 1) has an area of $195 \mathrm{~km}^{2}$ and a length of $27.3 \mathrm{~km}$, and its source is to the north of the city of Macapá. Its southern and eastern limits are the Amazon River; its western limit is the city of Santana and its northern limit is the region of the Curiaú river basin (Takiyama et al. 2004, Silva et al. 2009). It is an important tributary of the Amazon river system in the state of Amapá, in the eastern Amazon region of Brazil, and it is located at the estuarine coastal sector. It is characterized as a river system with extensive floodplains, constituting physical systems connected via a silted-up river that forms a drained for freshwater. It is influenced by high rainfall and the daily tides of the Amazon River, to which it is connected. The main channel of the Igarapé Fortaleza basin carries rich organic matter that is brought in by the tides of the Amazon river and is carried to the floodplain, which are protected environments.

Access to these floodplains is difficult for large predators and thus these areas form an environment that is favorable for development of different species of small and medium-sized fish. Several species of native fish are known in this basin and some are endemic. During the rainy season, the waters are rich in nutrients because of the fast decomposition of grass and animal remains and because the layer of humus that the forest produces is spread across the floodplain. This leads to great growth of vegetation and invertebrate biomass (insects, crustaceans and mollusks), which are used as food by fish (Takiyama et al. 2004). In addition, this hydrographic basin has been strongly influenced by invasion of Oreochromis niloticus, an exotic fish with a large population that preferentially concentrates in floodplain areas (Bittencourt et al. 2014b). The vegetation is formed by species of Poaceae, Cyperaceae and Arecaceae, which form the várzea forest along the waterways, along with species of the macrophytes Cabombaceae, Lentibulariaceae, Salviniaceae and Cyperaceae (Thomaz et al. 2004). 


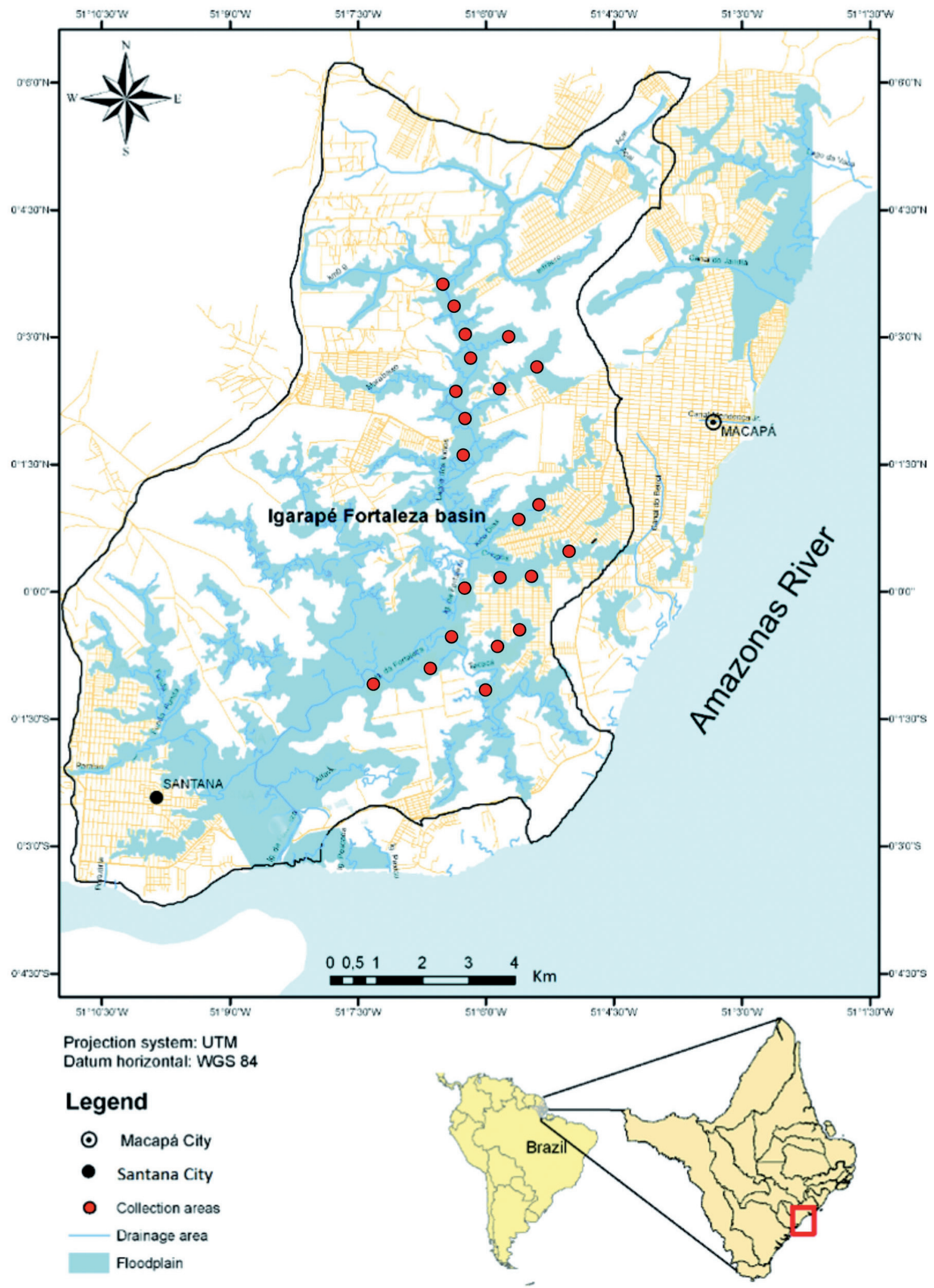

Fig. 1. Site of the fish collection in Igarapé Fortaleza hydrographic basin, a tributary of the Amazon river system in the state of Amapá, northern Brazil 
Table I. Host species, families, trophic level, number of hosts $(\mathrm{N})$, parasites richness and dominant taxon of parasites in fish of a tributary from the Amazon River, northern Brazil. * Based in Froese and Pauly (2017)

\begin{tabular}{|c|c|c|c|c|c|}
\hline Species of hosts & Host family & Trophic level* & $\mathbf{N}$ & $\begin{array}{c}\text { Parasites } \\
\text { richness }\end{array}$ & Dominant taxon \\
\hline Ageneiosus ucayalensis & Auchenipteridae & Carnivorous & 34 & 9 & Digenea \\
\hline Acestrorhynchus falcatus & Acestrorhynchidae & Piscivorous & 61 & 10 & Protozoa \\
\hline Acestrorhynchus falcirostris & Acestrorhynchidae & Piscivorous & 33 & 11 & Protozoa \\
\hline Leporinus friderici & Anostomidae & Omnivorous & 50 & 6 & Protozoa \\
\hline Auchenipterus nuchalis & Auchenipteridae & Carnivorous & 27 & 4 & Protozoa \\
\hline Trachelyopterus coriaceus & Auchenipteridae & Omnivorous & 35 & 7 & Protozoa \\
\hline Trachelyopterus galeatus & Auchenipteridae & Omnivorous & 37 & 6 & Protozoa \\
\hline Callichthys callichthys & Callichthyidae & Omnivorous & 38 & 5 & Digenea \\
\hline Hoplosternum litorale & Callichthyidae & Omnivorous & 43 & 2 & Protozoa \\
\hline Megalechis thoracata & Callichthyidae & Omnivorous & 38 & 5 & Digenea \\
\hline Hemibrycon surinamensis & Characidae & Omnivorous & 93 & 7 & Protozoa \\
\hline Aequidens tetramerus & Cichlidae & Omnivorous & 92 & 11 & Protozoa \\
\hline Astronotus ocellatus & Cichlidae & Carnivorous & 33 & 9 & Protozoa \\
\hline Chaetobrachus flavescens & Cichlidae & Omnivorous & 39 & 11 & Protozoa \\
\hline Chaetobranchopsis orbicularis & Cichlidae & Omnivorous & 32 & 9 & Protozoa \\
\hline Cichlasoma amazonarum & Cichlidae & Omnivorous & 112 & 7 & Protozoa \\
\hline Cichlasoma bimaculatum & Cichlidae & Omnivorous & 37 & 4 & Protozoa \\
\hline Laetacara curviceps & Cichlidae & Omnivorous & 20 & 7 & Protozoa \\
\hline Mesonauta acora & Cichlidae & Omnivorous & 38 & 7 & Protozoa \\
\hline Pterophyllum scalare & Cichlidae & Omnivorous & 42 & 7 & Protozoa \\
\hline Satanoperca jurupari & Cichlidae & Omnivorous & 30 & 9 & Protozoa \\
\hline Curimata incompta & Curimatidae & Omnivorous & 40 & 6 & Protozoa \\
\hline Curimata cyprinoides & Curimatidae & Omnivorous & 65 & 5 & Protozoa \\
\hline Hoplerythrinus unitaeniatus & Erythrinidae & Carnivorous & 69 & 15 & Protozoa \\
\hline Hoplias malabaricus & Erythrinidae & Carnivorous & 67 & 20 & Protozoa \\
\hline Ancistrus sp & Loricariidae & Detritivorous & 20 & 4 & Monogenea \\
\hline Harttia duriventris & Loricariidae & Detritivorous & 40 & 2 & Protozoa \\
\hline Hypostomus ventromaculatus & Loricariidae & Detritivorous & 21 & 5 & Digenea \\
\hline Peckoltia braueri & Loricariidae & Detritivorous & 39 & 7 & Digenea \\
\hline Pterygoplichthys pardalis & Loricariidae & Detritivorous & 33 & 3 & Digenea \\
\hline Squaliforma emarginata & Loricariidae & Detritivorous & 40 & 3 & Protozoa \\
\hline Metynnis lippincottianus & Serrasalmidae & Omnivorous & 80 & 10 & Protozoa \\
\hline Triportheus angulatus & Triportheidae & Omnivorous & 31 & 7 & Protozoa \\
\hline Triportheus curtus & Triportheidae & Omnivorous & 33 & 5 & Protozoa \\
\hline Triportheus rotundatus & Triportheidae & Omnivorous & 32 & 8 & Monogenea \\
\hline
\end{tabular}

Because this basin is located in a periurban area at the border between two municipalities, it is under pressure from urban land occupation. This has led to land reclamation from the water bodies for construction of housing, occurrences of burning of vegetation and solid waste dumping, and buffalo-rearing activities. Thus, the $\mathrm{pH}$ of the water varies from 5.5 to 7.5 and the oxygen levels from 2.5 to $6.0 \mathrm{mg} / \mathrm{L}$, depending on the area of basin and the seasonality (Takiyama et al. 2004).

\section{Data analysis}

Data from 82 parasite species that were found in 35 species of host fish were analyzed in relation to species and taxonomic group richness, prevalence, mean intensity and mean abundance (Bush et al. 1997), according to host trophic levels. The abundance and intensity data on the parasites, according to trophic level, were tested for normal distribution and ho- 
moscedasticity of variances. Since the abundance data did not present normal distribution, the Kruskal-Wallis test was used to investigate differences between trophic levels (Zar 2010). The network of 35 host fish species and 80 parasite associations was analyzed to evaluate parasite-host interaction patterns using the R statistical software (R core team 2017) and the bipartite package, which focuses on defining web patterns (Dormann et al. 2009).

In order to ascertain the similarity between the trophic levels of the hosts, a data matrix was constructed using the abundance of ectoparasites and endoparasites for each host population, according to the trophic levels of the host fish. This data matrix was subjected to cluster analysis using the BrayCurtis index (Krebs 1999), to test the null hypothesis of no difference in composition and abundance of the ectoparasite and endoparasite communities between detritivorous, carnivorous, omnivorous and piscivorous hosts, using the PAST software (Hammer et al. 2001). Non-metric multidimensional scaling (NMDS) with Bray-Curtis similarity distances, also using the ectoparasites and endoparasites abundance data for each host population, was used to evaluate the general pattern of similarity between host species. In this analysis, we used the R statistical environment ( $\mathrm{R}$ core team 2017) and the "Vegan" library (Oksanen et al. 2017).

Spearman's correlation coefficient ( $r s$ ) between ectoparasites and endoparasites abundance and length in each host population was used to ascertain whether larger fish tended to have higher abundance of parasites. Firstly, the normality of the data was evaluated through the Shapiro-Wilk test, since the data did not present normal distribution, even after logarithmic transformation and obtaining the arcsine square root, the Spearman correlation test was then used (Zar 2010).

\section{Results}

Among the 82 species of ectoparasites and endoparasites in the 1574 host fish, ectoparasites predominated. These were mainly protozoan species and they were present in 28 hosts $(80 \%)$. Metacercariae of Posthodiplostomum sp., Digenea gen. sp. and Clinostomum sp. were the parasites found, both in the gills (ectoparasites) and in the intestine (endoparasites) of the hosts. Hoplerythrinus unitaeniatus and Hoplias malabaricus presented the greatest richness of parasites, while Hoplosternum littorale and Harttia duriventris were the hosts with the lowest richness (Table I).

In the fish assemblage, the species richness of ectoparasites was greater than that of endoparasites (Fig. 2). Regarding the parasites taxa found, the greatest richness was of species of monogeneans, followed by nematodes and digeneans (Fig. 3).

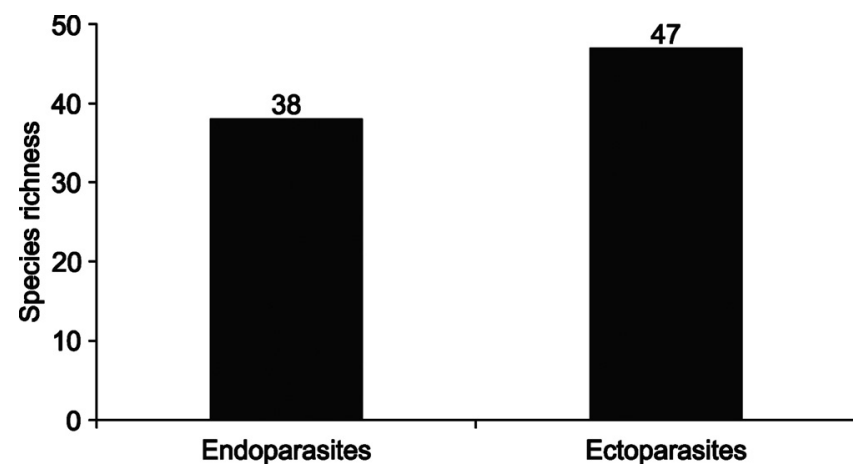

Fig. 2. Species richness of parasites in fish of a tributary from the Amazon river system, northern Brazil

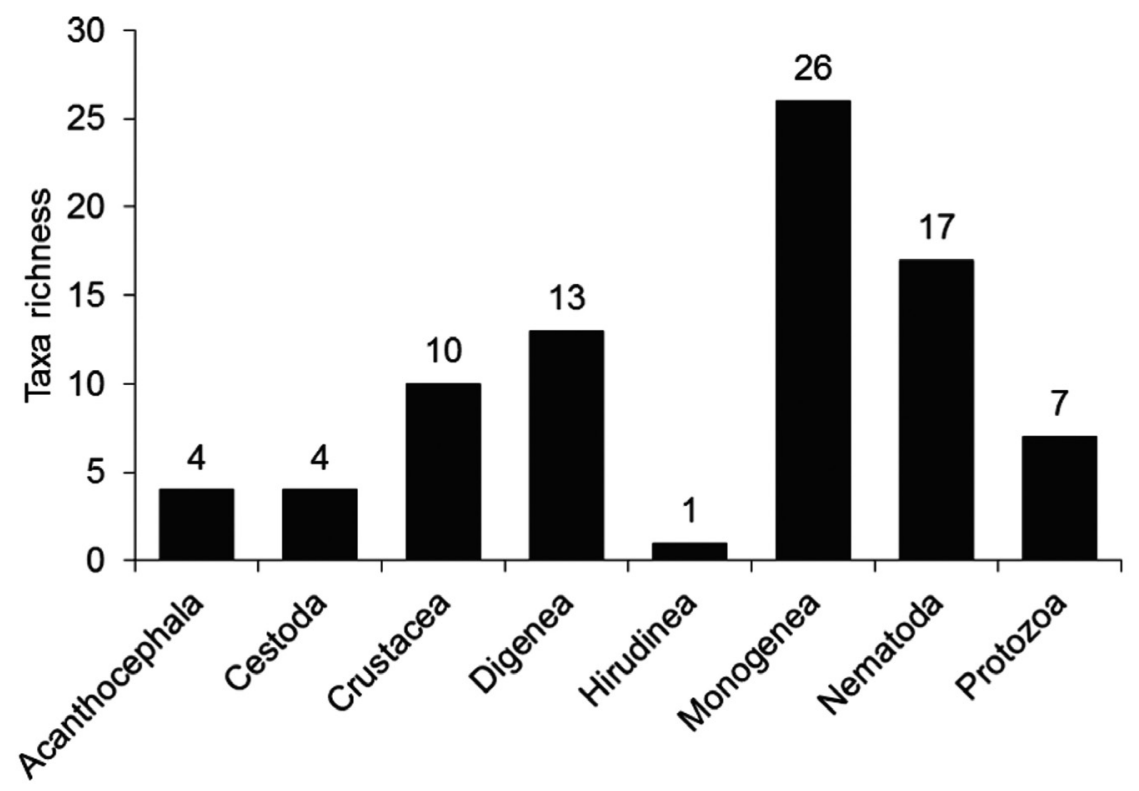

Fig. 3. Species richness of parasites according to zoological group, in fish of a tributary from the Amazon river system, northern Brazil 


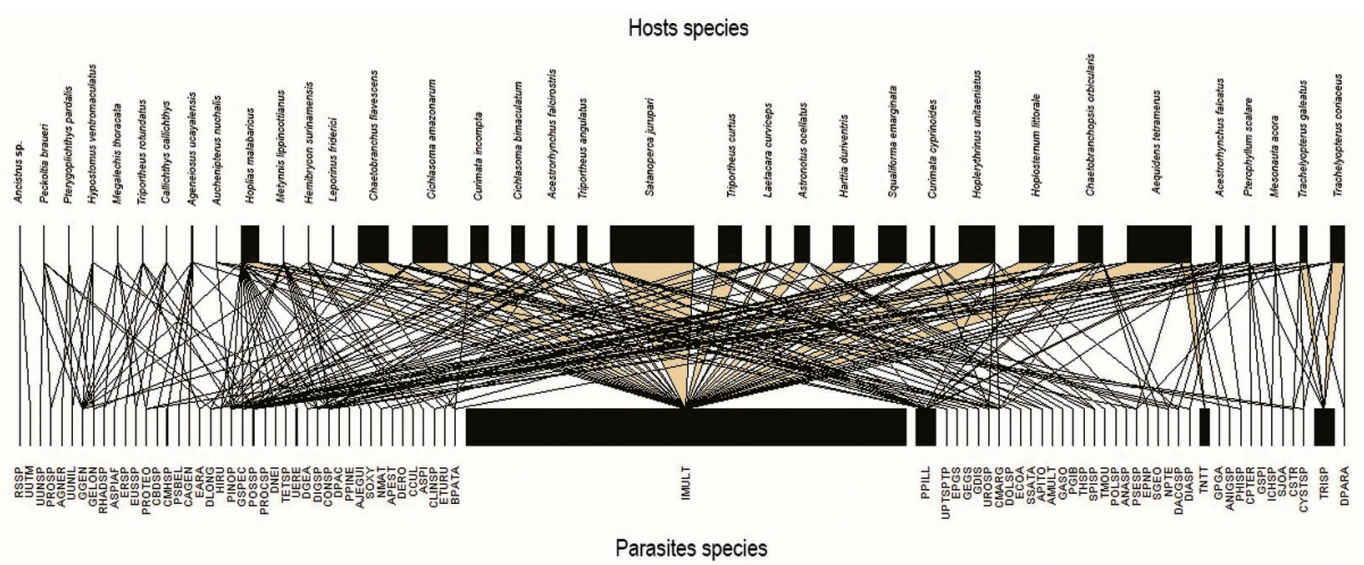

Fig. 4. Network of interactions between parasites and host fish species of a tributary from the Amazon river system, northern Brazil. IMULT: Ichthyophthirius multifiliis, PPILL: Piscinoodinium pillulare, DIASP: Diaphorocleidus sp., DACGSP: Dactylogyridae gen. sp., BPATA: Braga patagonica, ETURU: Ergasilus turucuyus, DIGSP: Digenea gen. sp., GPGA: Gussevia disparoides and Gussevia alioides, TNTT: Trichodina nobilis and Tripartiella tetramerii, DLONG: Dolops longicauda, CBDSP: Cosmetocleithrum bulbocirrus and Demidospermus sp., GASO: Gussevia asota, POSSP: Posthodiplostomum sp., AMULT: Argulus multicolor, CSTR: Cosmetocleithrum striatuli, HIRU: Hirudinea, SGEO: Sciadicleithrum geophagi, GDIS: Gussevia disparoides, UROSP: UrocleiDOIdes sp., SPISP: Spironucleus sp., ASPI: Argulus spinulosus, TMOU: Trinigyrus mourei, ANASP: Anacanthorus sp, CLINSP: Clinostomum sp., DGEA: Dolops geayi, APEST: Argulus pestifer, UUNIL: Unilatus unilatus, SJOA: Sciadicleithrum joanae, TRISP: Tripartiella sp., GSPI: Gussevia spilocirra, APITO: Anacanthorus pitophallus, TETSP: Tetrahymena sp., UERE: UrocleiDOIdes eremitus, UPTSPTP: UrocleiDOIdes paradoxus, Tereacistrum sp., Tereacistrum parvus, ECOA: Sciadicleithum satanopercae, SSATA: Ergasilus coatiarus, ASPIAF: Ancistrohaptor sp., Anacanthorus pithophallus and Anacanthorus furculus, ERSP: Ergasilus sp., DOLSP: Dolops sp., UUNSP: Unilatus unilatus and Nothogirodactylus sp., AJEGUI: Anacanthorum jegui, UUTM: Unilatus unilatus and Trinigyrus mourei, CMARG: Clinostomum marginatum, CONSP: Contracaecum sp., PHISP: Philometra sp., PINOP: Procamallanus (Spirocamallanus) inopinatus, NPTE: Neoechinorhynchus pterodoridis, DIGSP: Digenea gen. sp., GSPEC: Gorytocephalus spectabilis, PSESP: Pseudoproleptus sp., ANIGSP: Anisakidae gen. sp., PROTEO: Proteocephalidae, GGEN: Genarchella genarchella, PSBEL: Procamallanus (Spirocamallanus) belenensis, CAGEN: Cucullanus ageneiosus, CMHSP: Clinostomum marginatum and Herpetodiplostomum sp., POSSP: Posthodiplostomum sp., THSP: Thometrema sp., PGIB: Proteocephalus gibsoni, EUSSP; Eustrogylides sp., RHADSP: Rhaddochona sp, GEGS: Gussevia elephus and Gussevia spilocirra, EPGS: Echinorhynchus paranensis and Gorytocephalus spectabilis, EPNP: Echinorhynchus paranensis and Neoechinorhynchus pterodoridis, EARA: Echinorrhynchus paranensis, POLSP: Polymorphus sp., GELON: Gorytocephalus elongorchis, CCUL: Cucullanus cucullanus, DERO: Derogenidae gen. sp, CLINSP: Clinostomum sp., NMAT: Nomimoscolex matogrossensis, PROSP: Proteocephalus sp., ICHSP: Ichthyouris sp., CPTER: Capillaria pterophyllum, DPARA: Dadaytremoides parauchenipteri, CYSTSP: Cystidicoloides sp., AGNER: Acanthostomum gnerii, PROCSP: Procamallanus sp., DNEI: Dendrorchis neivai, SOXY: Spinoxyuris oxydoras, PPINE: Procamallanus pimelodus, DPAC: Dadayus pacupeva, RSSP: Raphidascaris Spentascaris sp.

Information on 80 associations of parasites with 35 species of hosts were analyzed. Ichthyophthirius multifiliis, Piscinoodinium pillulare and Tripartiella $\mathrm{sp}$. were the species of parasites that presented the greatest prevalence in hosts investigated. Among the hosts, the highest numbers of associations with the parasite species occurred in Satanoperca jurupari, Aequidens tetramerus, Hoplerythrinus unitaeniatus, Hoplosternum littorale, Cichlasoma amazonarum, Chaetobranchus flavescens, Squaliforma emarginata, Chaetobranchopsis orbicularis and Hoplias malabaricus. Among detritivorous hosts, I. multifiliis and Gorytocephalus elongorchis were most prevalent; among omnivorous hosts, I. multifiliis, Piscinoodinium pillulare, Procamallanus (Spirocamallanus) inopinatus and larvae of Contracaecum sp. and Posthodiplostomum sp.; among carnivorous hosts, I. multifiliis, Contracaecum sp. and P. (S) inopinatus; and among piscivorous hosts, I. multifiliis, P. pillulare and larvae of Clinostomum marginatum and Contracaecum sp. were most prevalent (Fig. 4).

The prevalence of ectoparasites and endoparasites was lower in detritivorous fish than in carnivorous, omnivorous and piscivorous fish. The mean intensity of ectoparasites was higher in detritivorous and omnivorous fish, while the mean intensity and abundance of endoparasites were higher in carnivorous and omnivorous fish (Table II).

Clustering according to trophic levels among the ectoparasite species presented a cophenetic correlation coefficient of 0.979 with 1,000 permutations. This showed that the species of detritivorous, omnivorous and carnivorous hosts formed a well-defined group, with greatest similarity between the detritivorous and omnivorous hosts (Fig. 5A). Clustering according to trophic levels among the endoparasite species presented a cophenetic correlation coefficient of 0.567 with 1,000 permutations. This showed that there was low similarity among the trophic levels of the hosts, because the piscivorous and detritivorous fish were different, while the omnivorous and carnivorous fish were closer (Fig. 5B).

The NMDS order indicated that the ectoparasites presented greater similarity among omnivorous, carnivorous and piscivorous fish species $\left(\mathrm{R}^{2}=0.999\right.$; stress $\left.=0.011\right)$ (Fig. 6B). 

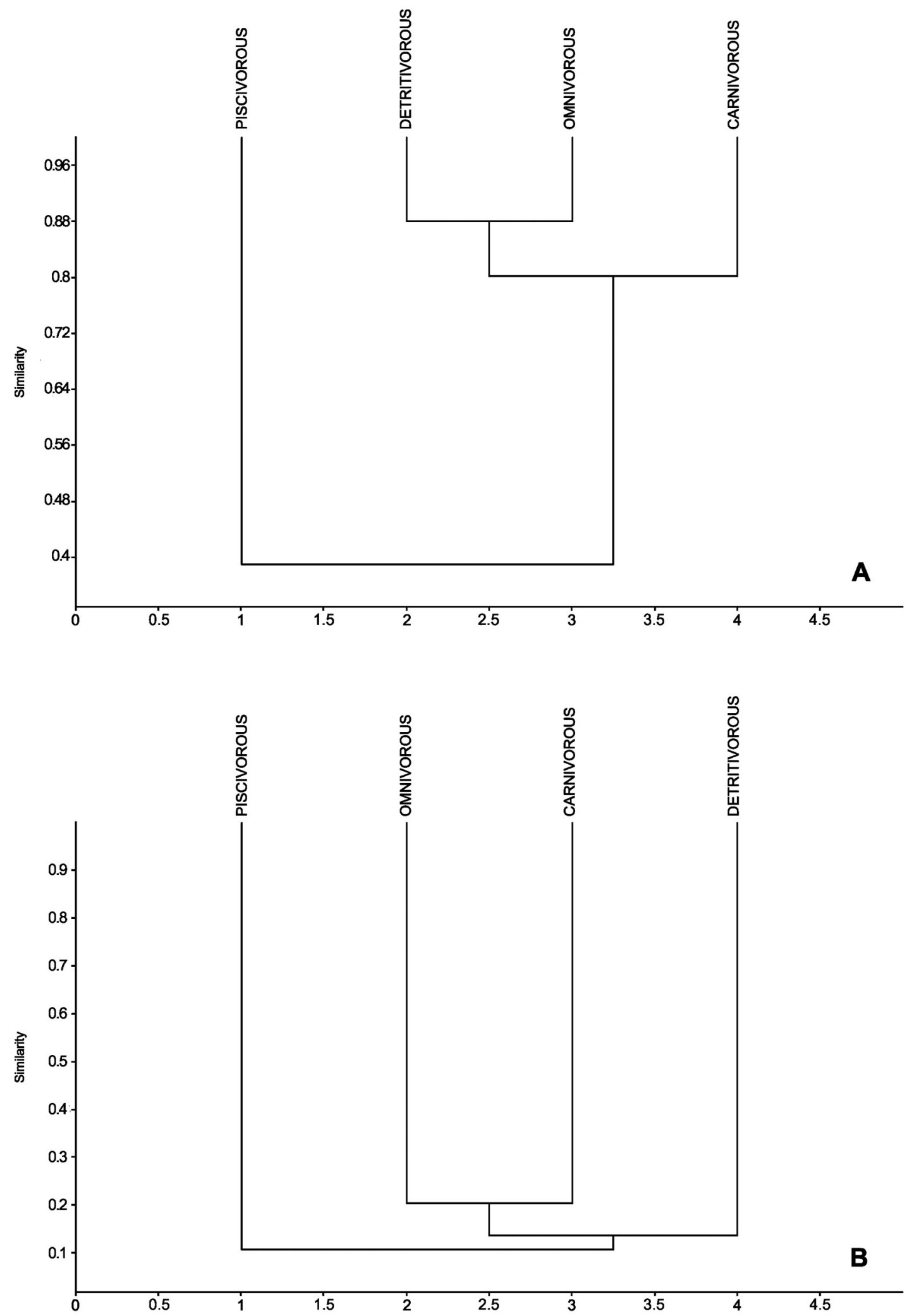

Fig. 5. Dendogram for similarity of Bray-Curtis index for ectoparasites (A) and endoparasites (B) community in host of different trophic levels of a tributary from the Amazon river system, northern Brazil 

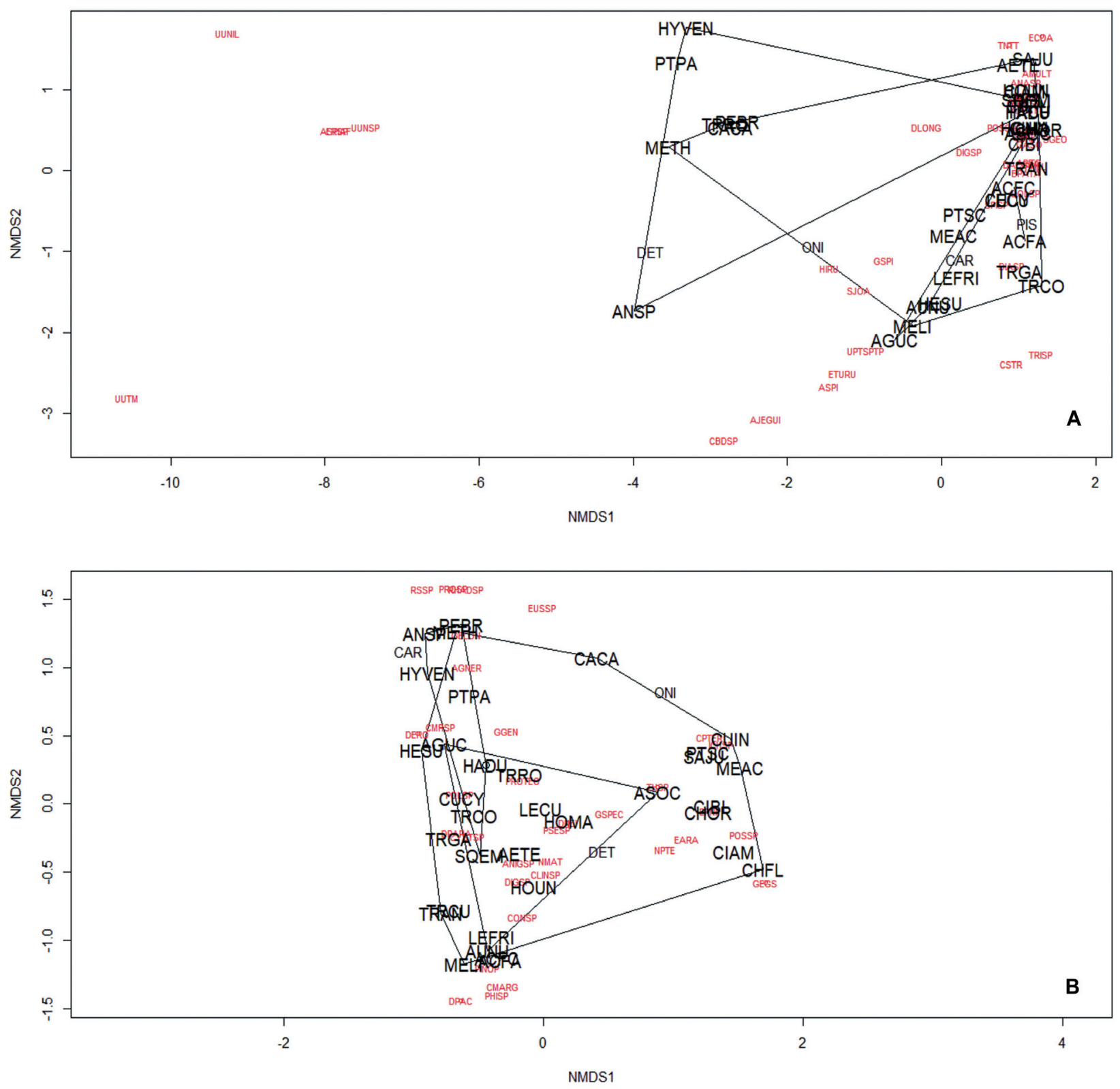

Fig. 6. Non-metric multidimensional scaling (NMDS) for species of ectoparasites (A) and endoparasites (B) according to hosts and its trophic levels in a tributary from the Amazon river system, northern Brazil. The polygons indicate the trophic levels of carnivorous (CAR), detritivorous (DET), omnivorous (ONI) and piscivorous (PIS) hosts

However, the NMDS order for endoparasites did not present any defined pattern, since the species of these parasites demonstrated random distribution among the hosts at the different trophic levels $\left(\mathrm{R}^{2}=0.997\right.$; stress $\left.=0.0581\right)$ (Figure 6A). In addition, the order showed a low stress value in relation to the number of axes.

A significant positive correlation $(r s=0.230 ; \mathrm{p}=0.0001)$ was found between ectoparasites abundance and host length, but it was low. There was no correlation $(r s=-0.041 ; \mathrm{p}=$ 0.185 ) between endoparasites abundance and host length (Fig.7A-B).

\section{Discussion}

The Amazon river basin is a center of diversity for most groups of Neotropical fish, with accordingly high levels of species richness of fish, as well as high richness of aquatic invertebrates and macrophytes (Albert and Reis 2011; Junk 2013; Garcez et al. 2017). This may influence the abundance of parasites in fish populations. Therefore, the aquatic vegetation of the hydrographic basin of this study plays an important role in structuring aquatic communities through providing breeding, refuge and feeding areas for the fish assemblage. At 

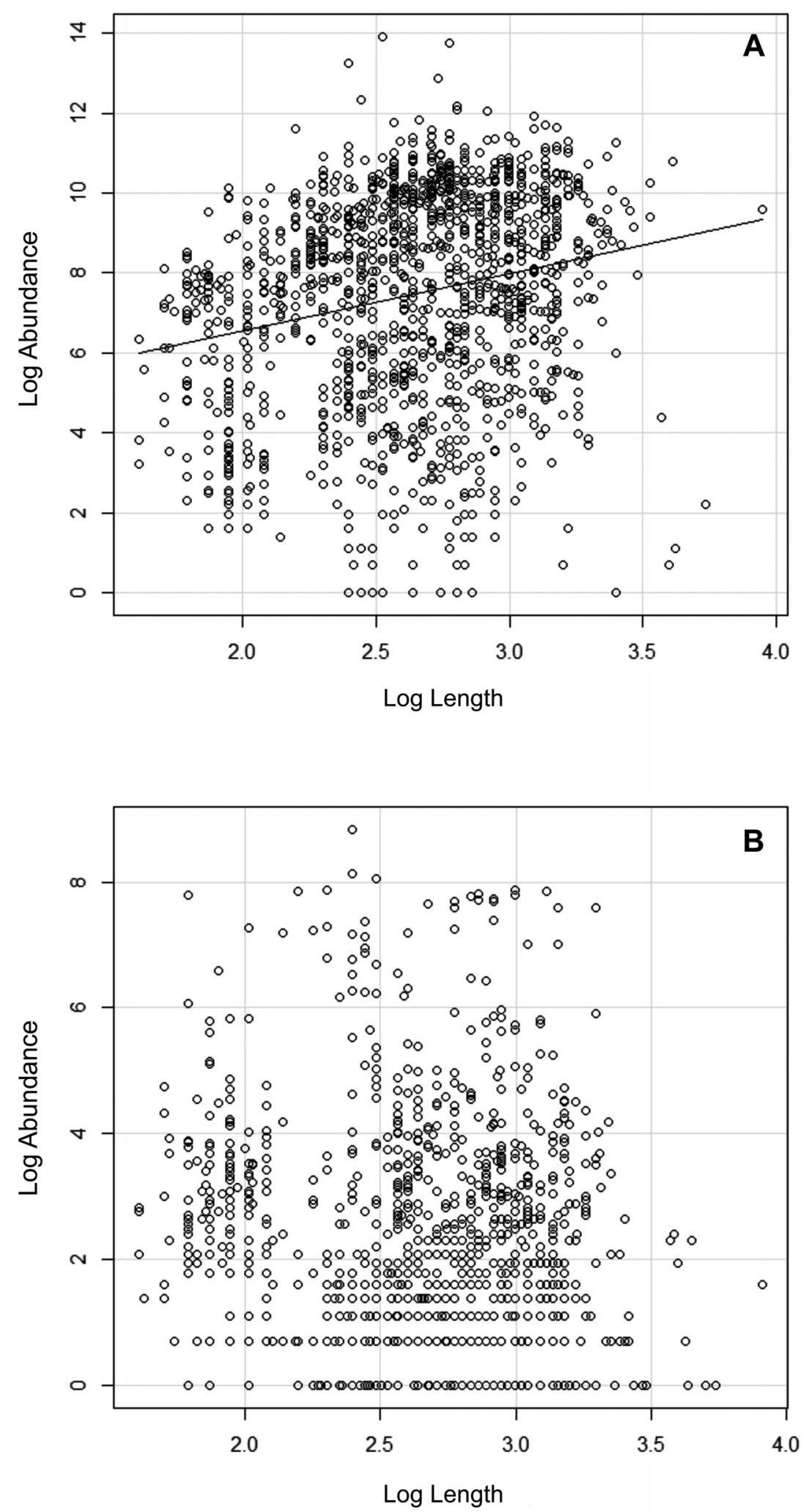

Fig. 7. Correlation of the abundance of ectoparasites (A) and endoparasites (B) with length of host fish of a tributary from Amazon river system, northern Brazil 


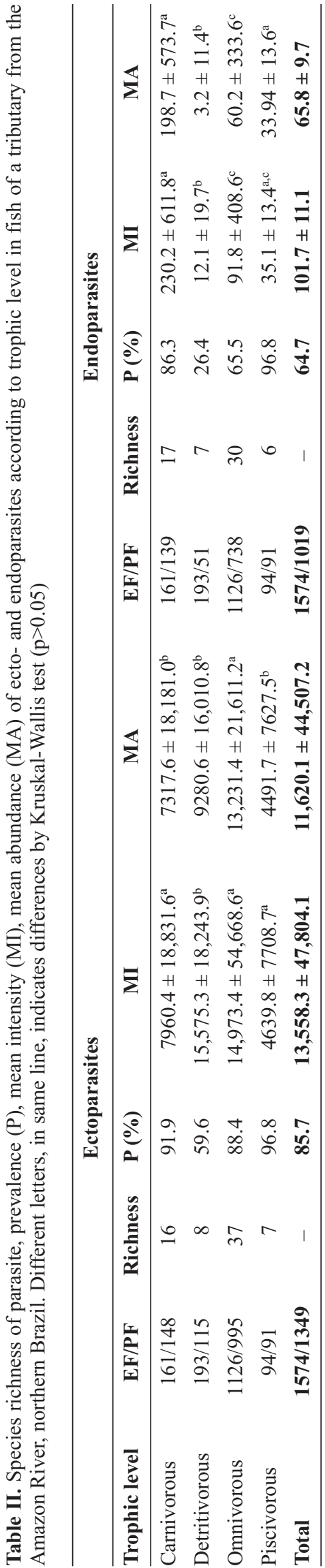

the same time, this vegetation increases the possibilities that these fish will acquire parasites (Tavares-Dias et al. 2014; Tavares-Dias et al. 2017; Garcez et al. 2017). Thus, the parasite community of the fish assemblage investigated was formed by 82 parasite species comprising protozoans, monogeneans, digeneans, cestodes, nematodes, acanthocephalans, crustaceans and hirudineans. However, monogeneans, nematodes and digeneans predominated. These taxonomic groups have also presented greater predominance in other Neotropical fish assemblages in different ecosystems (Luque and Poulin 2007; Bellay et al. 2015). Therefore, the parasite communities in this host assemblage reflect the presence of diverse vertebrate and invertebrate species that act as intermediate, paratenic and definitive hosts in the environment, thus supporting the life cycle of these parasitic taxa.

Fish parasites represent a large portion of aquatic biodiversity and can be directly affected by the environment or indirectly through their hosts (Grutter 1994; Marcogliese and Cone 1997; Choudhury et al. 2000; Poulin 2004a; Lafferty et al. 2008, Alcântara and Tavares-Dias 2015; Hoshino et al. 2016). Thus, parasite species are a significant part of food webs, have an impact on the trophic structure and may even comprise half of the host organizational diversity (Marcogliese and Cone 1997; Lafferty et al. 2008; Ruehle et al. 2017). Despite the importance of parasite populations, these ecological components of Amazonian ecosystems have been neglected for a long time. Studies extrapolating the total diversity of parasites in fish assemblages have been conducted in some geographical areas (Poulin 2004b). Choudhury and Dick (2000) conclude that in communities of tropical freshwater fish the mean helminth species richness is species-poor and not exceeded two. Later, Poulin (2001) found also a low helminth species richness in freshwater fish of tropical areas. We found three species of parasites (protozoans and metazoans) per host fish. However, the estimates of the total richness of parasite species for certain host groups in certain geographical areas are always much larger than the number of known parasite species (Poulin 2004a), especially in tropical ecosystems like in present study. Therefore, parasites communities of tropical freshwater fish are in fact species-poor, mainly endoparasites species. Parasites community structure and organization are highly complex due to the long and continuing interaction involving both host and parasite populations. Thus, parasite communities are influenced by the sum of a complex set of biotic (e.g. diet, size of hosts) and abiotic (e.g. geography of region, environmental conditions) factors which directly impact on processes that will affect the transmission dynamics of parasites, mainly helminth species (Kennedy 1990; Guégan et al. 1992; Choudhury and Dick 2000; Poulin 2001; PérezPonce de León and Choudhury 2005; Bellay et al. 2015).

In the food web, the trophic level of host populations may be a good indicator regarding these hosts' exposure to parasites. Fish at higher levels may be more frequently exposed to infective larval forms of a greater diversity of helminths in their diet than are those at lower trophic levels (Luque and Poulin 
2008; Valtonen et al. 2010; Poulin and Leung 2011; Timi et al. 2011; Beevi and Radhakrishnan 2012; Alcântara and Tavares-Dias 2015). The qualitative dissimilarity of the endoparasites was very marked for the herbivorous hosts. The two species of piscivorous hosts in the present study, Acestrorhynchus falcatus and Acestrorhynchus falcirostris (Acestrorhynchidae), were dissimilar regarding their ectoparasite and endoparasite communities in comparison with the detritivorous, omnivorous and carnivorous hosts. In addition, $H$. unitaeniatus and H. malabaricus (Erythrinidae), which are both carnivorous hosts, had greater parasite richness, mainly comprising ectoparasites. These species of Erythrinidae are carnivorous fish when young, feeding on plankton, crustaceans, aquatic insects and fish, and are usually active and do not migrate for spawning (Alcântara and Tavares-Dias 2015). Therefore, host trophic levels have a direct influence on the abundance and composition of endoparasite communities.

Host specificity also appears to be an important factor relating to the distribution of parasites, since the distribution of helminths reflects that of the fish families that they parasitize (Choudhury and Dick 2000; Poulin 2001; Pérez-Ponce de León and Choudhury 2005; Salgado-Maldonado et al. 2016). Given that assemblages of tropical fish can be very rich in species, they have parasites that may be equally available to most hosts. Thus, generalist parasites may also be numerous (Salgado-Maldonado et al. 2016). Among the taxa of parasites, we found greater richness of ectoparasites than of endoparasites, and with predominance of species of monogeneans, crustaceans and protozoans. Ichthyophthirius multifiliis, P. pillulare and Tripartiella sp. were the protozoans with the highest numbers of associations with the host species of this study, because they are opportunistic ectoparasites with a direct life cycle, which is favored by poorer environmental conditions (e.g. low $\mathrm{pH}$ and oxygen) in which urban eutrophication has a high impact (Takiyama et al. 2012; Bittencourt et al. 2014a,b; Hoshino et al. 2016). In contrast, the abundance of endoparasites can be negatively affected by these environmental characteristics, as well as by the behavior and density of host populations, among other factors (Bittencourt et al. 2014a; Bellay et al. 2015, Alcântara and Tavares-Dias 2015). Variations in endoparasite communities and in the abundance of these species can also be determined through changes to the host diet or the volume of food consumed containing infective parasites and through ontogenetic changes in immunocompetence, modification of the likelihood of contact and the degree of efficiency of potential intermediate hosts and parasites (Bellay et al. 2015; Salgado-Maldonado et al. 2016).

Native parasite species within a rich fauna generally occur in only a few species of host fish, since they are specialists, while the parasites in poor fauna are mostly generalist species (Bittencourt et al. 2014a). The specialists are an important part of the component community, but generalists dominate more often. However, when generalist parasites are absent, or scarce, do specialists dominate communities (Kennedy 1990). The parasite communities of the fish assemblage studied here pre- sented a small number of generalist ectoparasites such as I. multifiliis, Tripartiella sp., P. pillulare, Posthodiplostomum sp metacercariae, Braga patagonica, Ergasilus turucuyus and Dolops longicauda, and endoparasite species such as Genarchella genarchella, Posthodiplostomum sp., Gorytocephalus spectabilis, Proteocephalus gibsoni, Contracaecum sp. and Procamallanus (Spirocamallanus) inopinatus. In addition, this fish assemblage included a great number of specialist ectoparasites (e.g. Unilatus unilatus, Trinigyrus mourei, Gussevia disparoides, Gussevia alioides, Gussevia elephus, Gussevia spiralocirra, Sciadicleithrum geophagi, Sciadicleithrum joanae, Sciadicleithrum satanopercae and Gussevia asota) and a small number of specialist endoparasites (e.g. Gorytocephalus elongorchis and Neoechinorhynchus pterodoridis). Therefore, for these parasite species, the generalist or specialist strategy may increase or reduce their ranges of host species. Given that the same endoparasite species are present in more than one host species; this indicates the existence of new intermediate hosts in the environment, along with the fact that different species of fish share one or more food items in the environment (Marcogliese 2002).

We found high prevalence of both ectoparasites and endoparasites in the fish assemblage. However, the prevalence of ectoparasites and endoparasites was lower in detritivorous hosts than in carnivorous, omnivorous and piscivorous fish. The mean intensity of ectoparasites was higher in detritivorous and omnivorous hosts, but the mean intensity and abundance of endoparasites were higher in carnivorous and omnivorous hosts. A previous study on the fauna of metazoan parasites in herbivorous, omnivorous and carnivorous freshwater fish also found that both the prevalence and mean intensity were higher in omnivorous and carnivorous hosts, thus indicating that the feeding habits of hosts was a determining factor relating to the parasite fauna (Beevi and Radhakrishnan 2012). According to Valtonen et al. (2010), piscivorous hosts (which appeared to be dominant consumers) and relatively large omnivorous hosts were heavily parasitized and were presumably important predators. On the other hand, small planktivorous and benthivorous hosts were likely to be important prey and had lower prevalence and abundance of parasites.

In host-parasite networks, the host body provides a microhabitat for parasite species of different lineages and with different life history strategies (Bellay et al. 2013). Host size has been correlated with trophic level and vulnerability, and also possibly with how many burden parasites are harbored. Since predators are larger than their prey, host body size within a food web tends to increase burden parasites with increasing trophic level (Valtonen et al. 2010; Poulin and Leung 2011). The detritivorous hosts of our study have lower chances of becoming infected by endoparasites because of the limited feeding of detritus, which decreases the chances of acquiring infections by heteroxenic parasites in comparison with omnivorous, carnivorous and piscivorous hosts that has several invertebrates in feeding. Both species of piscivorous hosts that were examined here (A. falcatus and A. falcirostris) are 
fish of medium size, like the species of carnivorous hosts and a large number of omnivorous hosts (e.g. species of Cichlidae), and had similar loads of endoparasites. Smaller species of omnivorous hosts (e.g. Hemibrycon surinamensis, Triportheus angulatus, Triportheus rotundatus, Triportheus curtus and Metynnis lippincottianus), which are prey for piscivorous, carnivorous and omnivorous fish with a tendency towards piscivorous behavior, were also found to have similar loads of endoparasites (Alcântara and Tavares-Dias 2015; Hoshino et al. 2016). However, we used parasites and host fish as indicators of trophic interactions independent of the items of the hosts' diet (which we did not evaluate), to infer links in the food web. In addition, the life cycle of most of the endoparasites found, which use different hosts at different stages of their development, remain unknown. However, according to Valtonen et al. (2010), parasites transmitted through trophic interactions may be used to help construct vertebrate sub-webs and derive information about food web processes. The parasites alone provided equivalent if not more information than observations regarding diet. However, resolution is improved by using parasites and the observed diet together.

For parasites in particular, the host body size constitutes another crucial variable influencing their ecology and evolution (Guégan et al. 1992; Walker et al. 2017). Host body size has long been considered a determinant of parasite species richness, although it generally explains only a portion of the interspecific variance in the numbers of parasite species infecting different host species (Guégan et al. 1992; Poulin 2004a; Valtonen et al. 2010; Poulin and Leung 2011). However, correlation of parasite abundance with host body size is far from universal (Grutter 1994; Poulin 2004a; Alcântara and Tavares-Dias 2015). Body length in fish assemblage of the present study showed a positive correlation with ectoparasites abundance, although the coefficient of this correlation was low, such that only $23 \%$ of the data showed a correlation. In contrast, for endoparasites, no correlation between length and parasite abundance was observed. In larger hosts, the niches available to parasites for colonization are more diverse, thus allowing hosts to harbor a higher parasite species richness (Kuris et al. 1980; Grutter 1994; Poulin 2001; Poulin 2004b) and parasites load, especially of ectoparasites. The ectoparasites recorded here were mostly $(90 \%)$ species that parasitize the gills. In larger hosts, the gills have more space to harbor parasites, thus influencing parasites abundance (Grutter 1994).

In conclusion, we found that in the fish assemblage investigated here, most of the host species had similar ectoparasites fauna and species richness, independent of the trophic level, except for piscivorous hosts. Carnivorous and omnivorous hosts harbored parasite communities that were more homogenous than those of detritivorous and piscivorous hosts, thus indicating that the feeding habits of hosts were an important factor influencing the presence of parasites. Therefore, hosts in the middle and higher parts of the food web, which fed on both invertebrates and small fish, harbored greatest diversity of endoparasite species. A small number of helminth endoparasites were specialist parasites, with specificity for intermediate and definitive hosts. Many generalist endoparasites had life cycles consisting of larval stages and probably only spent short spans of their lives in intermediate and paratenic hosts. These characteristics seem to be adaptations to the food web and to the high densities of organisms distributed over wide spatial scales that are common in Amazonian ecosystems. The parasite communities of the fish assemblage were a set of the local fauna and the parasite richness found here was not a reflection of all the fauna that exists in the ecosystem. The species richness of the parasites in the component communities may have been influenced by the availability of local parasite species and probability the availability of hosts for colonization. Finally, the body length of the hosts was not an important predictor of parasite abundance in this fish assemblage.

Acknowledgements. M. Tavares-Dias was granted (\# 303013/20150) a Research Fellowship from the National Council for Scientific and Technological Development (CNPq, Brazil). The authors thank Dr. Juan T. Timi, of the Universidad Nacional de Mar del Plata (Argentina), for his critical review of the manuscript prior to submission.

\section{References}

Albert J.S., Reis R.E. 2011. Introduction to Neotropical freshwaters. In: Albert J.S., Reis R.E. (Eds). Historical biogeography of Neotropical freshwater fishes. University of California Press, Berkeley, pp. 3-19

Alcântara N.M., Tavares-Dias, M. 2015. Structure of the parasite communities in two Erythrinidae fish from Amazon River system (Brazil). Brazilian Journal of Veterinary Parasitology, 24, 183-190

Beevi M.R., Radhakrishnan S. 2012. Community ecology of the metazoan parasites of freshwater fishes of Kerala. Journal of Parasitic Diseases, 36, 184-196

Bellay S., Oliveira E.F., Almeida-Neto M., Lima-Junior D.P., Takemoto R. M., Luque J.L. 2013. Developmental stage of parasites influences the structure of fish-parasite networks. Plos One, 8, e75710. DOI:10.1371/journal.pone.0075710

Bellay S., Oliveira E.F., Almeida-Neto M., Abdallah V.D., Azevedo R.K., Takemoto R. M., Luque J.L. 2015. The patterns of organization and structure of interactions in a fish-parasite network of a Neotropical river. International Journal for Parasitology, 45, 549-557. DOI: http://dx.DOI.org/ 10.1016/ j.ijpara.2015.03.003

Bittencourt L.S., Pinheiro D.A., Cárdenas M.Q., Fernandes B.M., Tavares-Dias M. 2014a. Parasites of native Cichlidae populations and invasive Oreochromis niloticus (Linnaeus, 1758) in tributary of Amazonas River (Brazil). Brazilian Journal of Veterinary Parasitology, 23, 44-54

Bittencourt L.S., Silva U.R.L., Silva L.M.A. Tavares-Dias M. 2014b. Impact of the invasion from Nile tilapia on natives Cichlidae species in tributary of Amazonas River, Brazil. Biota Amazônia, 4, 88-94

Bush A.O., Lafferty K.D., Lotz J.M., Shostak W. 1997. Parasitology meets ecology on its own terms: Margolis et al. Revisited. Journal of Parasitology, 83, 575-583 
Choudhury A., Dick T.A. 2000. Richness and diversity of helminth communities in tropical freshwater fishes: empirical evidence. Journal of Biogeography, 27, 935-956

Dormann C.F., Fruend J., Bluethgen N., Gruber B. 2009. Indices, graphs and null models: analyzing bipartite ecological networks. The Open Ecology Journal, 2, 7-24

Froese R., Pauly D., Editors. 2017. Fish Base. World Wide Web electronic publication. www.fishbase.org, version (06/2017)

Garcez R.C.S., Souza, L.A., Frutuoso M.E., Freitas C.E.C. 2017. Seasonal dynamic of Amazonian small-scale fisheries is dictated by the hydrologic pulse. Boletim do Instituto da Pesca, 43, 207-221

Guégan J.F., Lambert A., Lévêdque C., Combes C., Euzet L. 1992. Can host body size explain the parasite species richness in tropical freshwater fishes? Oecologia , 90, 197-204. DOI: 10.1007/BF00317176

Grutter A.S. 1994. Spatial and temporal variations of the ectoparasites of seven reef fish species from Lizard Island and Heron Island, Australia. Marine Ecology Progress Series, 115, 21-30

Hammer O., Harper D.A.T., Ryan P.D. 2001. PAST: paleontological statistics software package for education and data analysis. Palaeontologia Electronica, 4, 1-9

Hoshino M.D.F.G., Neves L.R., Tavares-Dias M. 2016. Parasite communities of the predatory fish, Acestrorhynchus falcatus and Acestrorhynchus falcirostris, living in sympatry in Brazilian Amazon. Brazilian Journal of Veterinary Parasitology, 25, 207-216. DOI: http://dx.DOI.org/10.1590/ S1984-29612016038

Junk W.J. 2013. Current state of knowledge regarding South America wetlands and their future under global climate change. Aquatic Sciences, 75, 113-131

Lafferty K.D., Allesina S., Arim M., Briggs C.J., De Leo G., Dobson A.P., et al. 2008. Parasites in food webs: the ultimate missing links. Ecology Letters, 11, 533-546. DOI: 10.1111/j.14610248.2008.01174.x

Kennedy C.R. 1990. Helminth communities in freshwater fish: structured communities or stochastic assemblages? In: Esch G.W., Busch A.O, Aho J.M. (Eds) Parasite communities: patterns and processes. Chapman and Hall, pp. 131-156

Krebs C.J. 1999. Ecological methodology. Addison-Wesley Educational Publishers, pp. 581

Kuris A.M., Blaustein, A.R., Alió J.J. 1980. Hosts as islands. American Naturalist, 116, 570-586

Luque J.L., Poulin R. 2007. Metazoan parasite species richness in Neotropical fishes: hotspots and the geography of biodiversity. Parasitology, 134, 865-878.

Luque J.L., Poulin R. 2008. Linking ecology with parasite diversity in Neotropical fishes. Journal of Fish Biology, 72, 189-204. DOI:10.1111/j.1095-8649.2007.01695.x

Marcogliese D.J. 2002. Food webs and the transmission of parasites to marine fish. Parasitology, 124, 83-99

Marcogliese D.J., Cone D.K. 1997. Food webs: a plea for parasites. Trends in Ecology \& Evolution, 12, 320-325

Oksanen J.F., Blanchet G., Friendly M., Kindt R., Legendre P., McGlinn D., Minchin P.R., O'Hara R. B., Simpson G.L., Solymos P., Stevens M.H.H., Szoecs E., and Wagner H. 2017. Vegan: Community Ecology Package. R Package version 2.4 3. https://CRAN.R-project.org/package=vegan

Pérez-Ponce de León, Choudhury A. 2005. Biogeography of helminth parasites of freshwater fishes in Mexico: the search for patterns and processes. Journal of Biogeography, 32, 645-659

Poulin R. 2001. Another look at the richness of helminth communities in tropical freshwater fishes. Journal of Biogeography, 28, 737-743

Poulin R. 2004a. Macroecological patterns of species richness in parasite assemblages. Basic Applied Ecology, 5, 423-434

Poulin R. 2004b. Parasite species richness in New Zealand fishes: a grossly underestimated component of biodiversity? Diversity and Distributions, 10, 31-37

Poulin R., Leung T.L.F. 2011. Body size, trophic level, and the use of fish as transmission routes by parasites. Oecologia, 166, 731738. DOI 10.1007/s00442-011-1906-3

R Core Team. 2017. R: A language and environment for statistical computing. R Foundation for Statistical Computing, Vienna, Austria. URL https://www.R-project.org.

Ruehle B.P., Herrmann K.K., Higgins, C.L. 2017. Helminth parasite assemblages in two cyprinids with different life history strategies. Aquatic Ecology, 51, 247-256

Valtonen E.T., Marcogliese D.J., Julkunen M. 2010. Vertebrate diets derived from trophically transmitted fish parasites in the Bothnian Bay. Oecologia, 162, 139-152

Salgado-Maldonado G., Novelo-Turcotte M.T., Caspeta-Mandujano J.M., Vazquez-Hurtado G., Quiroz-Martínez B., MercadoSilva N., Favila M. 2016. Host specificity and the structure of helminth parasite communities of fishes in a Neotropical river in Mexico. Parasite, 23, 61. DOI: 10.1051/parasite/ 2016073

Silva A.Q., Takiyama L.R., Costa-Neto S.V., Silveira O.F.M. 2009. Valoração ambiental das unidades fitoecológicas remanescentes da bacia hidrográfica do Igarapé Fortaleza. OLAM Ciência \& Tecnologia, 9, 354-384

Takiyama L.R., Silva A.Q., Costa W.J.P., Nascimento H.S. 2004. Qualidade das águas das ressacas das bacias do Igarapé da Fortaleza e do Rio Curiaú. In: (Eds. Takiyama L.R., Silva A.Q). Diagnostico das ressacas do Estado do Amapá: bacias do Igarapé da Fortaleza e Rio Curiaú, Macapá-AP. CPAQ/IEPA e DGEO/SEMA, Macapá, pp. 81-104. (In Portuguese)

Takiyama L.R., (et al.). 2012. Projeto zoneamento ecológico econômico urbano das áreas de ressacas de Macapá e Santana, estado do Amapá: relatório técnico final. Luis Roberto Takiyama. Macapá: IEPA, pp. 84 (In Portuguese)

Tavares-Dias M., Oliveira M.S.B., Gonçalves R.A., Silva L.M.A. 2014. Ecology and seasonal variation of parasites in wild $A e-$ quidens tetramerus, a Cichlidae from the Amazon. Acta Parasitologica, 59,158-164. DOI: 10.2478/s11686-014-0225-3

Tavares-Dias M., Gonçalves R.A., Oliveira M.S.B., Neves L.R. 2017. Ecological aspects of the parasites in Cichlasoma bimaculatum (Cichlidae), ornamental fish from the Brazilian Amazon. Acta Biológica Colombiana, 22, 175-180. DOI: http://dx.DOI.org/10.15446/abc.v22n2.60015

Thomaz D.O., Costa Neto S.V., Tostes L.C.L. 2004. Inventario florístico das ressacas das bacias do Igarapé da Fortaleza e do Rio Curiaú. In: (Eds. Takiyama L.R., Silva A.Q). Diagnostico das ressacas do Estado do Amapá: bacias do Igarapé da Fortaleza e Rio Curiaú, Macapá-AP. CPAQ/IEPA e DGEO/SEMA, Macapá, pp. 1-22 (In Portuguese)

Timi J.T., Rossin M.A., Alarcos A.J., Braicovich P.E., Cantatore D.M.P., Lanfranchi A.L. 2011. Fish trophic level and the + similarity of non-specific larval parasite assemblages. International Journal for Parasitology, 41, 309-316. DOI: 10.1016/j.ijpara.2010.10.002

Walker JG, Hurford A, Cable J, Ellison AR, Price SJ, Cressler CE. 2017. Host allometry influences the evolution of parasite host-generalism: theory and meta-analysis. Philosophical Transactions of the Royal Society B, 372, 20160089. http://dx.DOI.org/10.1098/rstb.2016.0089

Zar J.H. 2010. Biostatistical analysis. $5^{\text {th }}$ ed. Prentice Hall, New Jersey, pp. 944

Received: November 13, 2017

Revised: January 18, 2018

Accepted for publication: January 19, 2018 